\title{
Constitutive Equation for Plastic Behavior of Hydrostatic Pressure Dependent Polymers
}

by

\author{
Yukio Sanomura*
}

Hydrostatic pressure dependence in mechanical behavior of polymers is studied for the constitutive modeling with the yield surface described by the first invariant and the second invariant of stress and the nonassociated flow rule satisfying incompressible hypothesis. An internal variable theory of rate-independent plasticity is presented incorporating isotropic hardening as a function of accumulated plastic strain. After determination of material constants under uniaxial tension and compression, the model shows that the von Mises type effective stress - plastic strain curves under multiaxial load are quite different from those under uniaxial load. The model is compared with the experimental results in uniaxial tension and compression by Spitzig and Richmond and in torsion by Silano et. al under high pressure.

Key words : Constitutive equation, Polymer, Plastic behavior, Hydrostatic pressure dependence, Nonassociated flow rule

\section{1 緒}

言

高分子材料の力学的挙動は, 温度依存性, 時間依存性, 変形誘起異方性ならびに静水圧依存性が著しい，時間依 存性として，流動応力のひずみ速度依存性，応力緩和な らびにクリープを記述するために, Kremplの粘塑性構

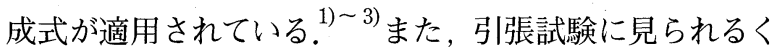
びれの発生とくびれの伝ば挙動を記述するために, Boyce らによって高分子鎖の回転や配向などの微視的内部構造 変化を反映できる分子鎖網目理論による構成式が提案さ れている.'5)

一方高圧力下での高分子材料の力学的挙動は, 数多く 研究されている. ${ }^{611)}$ これらの実験結果から高分子材料 では, 力学的挙動に及ぼす静水圧依存性が金属材料と比 べて著しいことがわかる。すなわち, 高分子材料の縦弾 性係数や横弾性係数ならびに降伏応力は, 圧力の増加に 伴ってほぼ直線的に増大する. ${ }^{6)}$ ） おける応力ーひずみ曲線は一致しない. ${ }^{9), 10)}$ その差は温度 の低下に伴って顕著となる. ${ }^{9}$ また, 多軸負荷状態におけ る降伏条件は, 静水圧の効果を応力の第一不変量で記述 して, Mises の降伏条件を修正することができる. ${ }^{12), 13)}$ したがって，高分子材料の塑性構成式は，静水圧依存性 を適切に表現する必要がある。

また金属材料の延性破壊挙動を記述するために，静水 圧依存性を考慮した多くの塑性構成式モデルが提案され

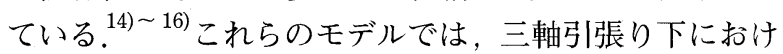
る空隙の生成・成長をスカラ变数で記述し，空隙を含む 多孔質材料の塑性構成式が定式化されている.しかし， これをそのまま高分子材料に適用しても上述の効果を表 現することはできない.
本研究では, 静水圧依存性のある降伏曲面と非連合流 れ法則を仮定した塑性構成式モデルを提案する。まず， 降伏曲面を応力の第 1 不変量と偏差応力の第 2 不変量で 記述し, 塑性変形の非圧縮性を満足するような塑性ポテ ンシャルで流れ法則を規定した。また等方硬化変数を相 当塑性ひずみの関数として定義し，その具体的な形を単 軸引張りの応力一塑性ひずみ曲線から求める。さらに， 単軸負荷における実験結果を記述するように，構成式の 材料定数を決定し, 多軸組合せ負荷における計算結果を 示す。最後に，高圧力下に打ける Spitzig と Richmond の実験結果 ${ }^{10)}$ ならびに Silano ${ }^{8)} ら の$ 実験結果と計算結果 を比較する。

\section{2 塑性構成式モデル}

高分子材料は，常温においても時間依存性が著しい. しかし，FEM などを用いた構造解析においては，まず第 1 次近似として，時間依存性を無視することがある。し たがって, 本報では簡単のため微小変形と時間依存性を 無視した塑性構成式の定式化を行う。材料の全ひずみ $\varepsilon_{i j}$ は, 弾性ひずみ $\varepsilon_{i j}^{e}$ と塑性ひずみ $\varepsilon_{i j}^{p}$ の和として次のよう に便宜上表す。

$$
\varepsilon_{i j}=\varepsilon_{i j}^{e}+\varepsilon_{i j}^{p}
$$

材料の弾性変形は Hooke の法則に従うものとすれば

$$
\varepsilon_{i j}=\frac{1+v}{E} \sigma_{i j}-\frac{v}{E} \sigma_{k k} \delta_{i j}
$$

と書ける。ここで $E$ と $v$ は，それぞれ縦弾性係数ならび にポアソン比を表す。な拈高分子材料では，一般に $E$ と $v$ は, 静水圧依存性がある. ${ }^{17)}$

次に，塑性変形を定式化する。静水圧依存性のある降 伏曲面の最も簡単な形は，次のように書ける.

$\dagger \quad$ 原稿受理 平成 12 年 8 月 25 日 Received Aug. 25,2000

* 正 会 員 玉川大学工学部機械工学科 †194-8610 町田市玉川学園, Dept. of Mech. Eng., Tamagawa Univ., Tamagawagakuen, Machida, 194-8610 


$$
\left.\begin{array}{l}
f=(1-\beta) \sqrt{3 J_{2}}+\beta I_{1}-\kappa=0 \\
J_{2}=\frac{1}{2} s_{i j} s_{i j}, \quad I_{1}=\sigma_{k k}
\end{array}\right\}
$$

ここで, $J_{2}$ と $I_{1}$ はそれぞれ偏差応力の第 2 不変量と応力 の第 1 不変量を表す。また， $\kappa$ は等方硬化変数を表す. なお， $\beta$ は材料定数である。 $\beta=0$ のとき，式 (3) は Mises の降伏曲面を表す. Fig. 1 は，式 (3)の降伏曲面 を主応力平面で表現したものである，図中の $\sigma_{Y}$ は，単 軸引張りの降伏応力である.

文献（10）によれば，高分子材料の塑性変形後の体積 変化は, 鋼と同様に著しく小さい.すなわち塑性変形の 非圧縮性をほぼ満足する。このような塑性ポテンシャル として次のように仮定することができる.

$$
g=\sqrt{3 J_{2}}
$$

したがって，非連合流れ則を用いれば，塑性ひずみ速度は

$$
\dot{\varepsilon}_{i j}^{p}=\lambda \frac{\partial g}{\partial \sigma_{i j}}
$$

のように書ける。ここで，入は応力および負荷履歴に依 存する正值のスカラー関数である。それは, Pragerの適 応の条件

$$
\dot{f}=\frac{\partial f}{\partial \sigma_{i j}} \dot{\sigma}_{i j}+\frac{\sigma f}{\partial \kappa} \dot{\kappa}=0
$$

を用いて求めることができ

$$
\left.\begin{array}{l}
\dot{\varepsilon}_{i j}^{p}=\frac{3}{2 H}\left[\frac{3}{2}(1-\beta) \frac{s_{k l}}{\sqrt{3 J_{2}}}+\beta \delta_{k l}\right] \dot{\sigma}_{k l} \frac{s_{j l}}{\sqrt{3 J_{2}}} \\
H=\frac{d \bar{\sigma}}{d \overline{\varepsilon^{p}}}
\end{array}\right\}
$$

を得る。ここで相当応力と相当ひずみは

$$
\left.\begin{array}{l}
\bar{\sigma}=(1-\beta) \sqrt{3 J_{2}}+\beta I_{1} \\
\overline{\varepsilon^{p}}=\left(\frac{2}{3} \varepsilon_{i j}^{p} \varepsilon_{i j}^{p}\right)^{1 / 2}
\end{array}\right\}
$$

で定義する。また等方硬化変数は

$$
\kappa=\bar{\sigma}\left(\overline{\varepsilon^{p}}\right)
$$

とおき, その具体的な関数形は単軸引張りの応力一塑性 ひずみ曲線から得られる。ここでは, 次の 2 種類の関数 形を検討する。すなわち

$$
\bar{\sigma}=F\left(b+\overline{\varepsilon^{p}}\right)^{n}
$$

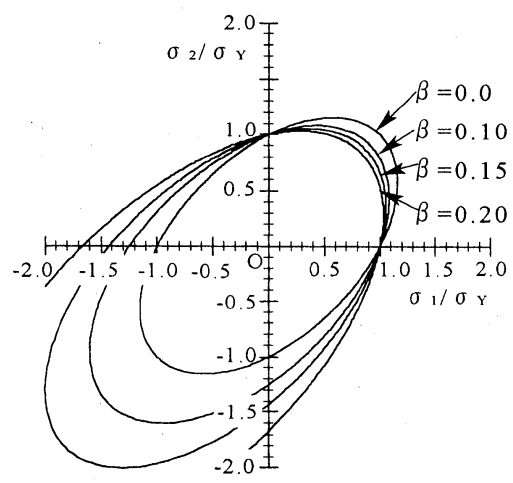

Fig. 1. Yield locus predicted by eq.(3) for various $\beta$.

$$
\bar{\sigma}=\sigma_{Y}+\left(\sigma_{Y}^{*}-\sigma_{Y}\right)\left[1-\exp \left(-c \overline{\varepsilon^{p}}\right)\right]
$$

なお， $F, b, n, \sigma_{Y}, \sigma_{Y}{ }^{*}, c$ は，材料定数である.

\section{3 種々の多軸比例負荷における計算結果}

\section{$3 \cdot 1$ 単軸負荷における実験結果と計算結果}

単軸引張りおよび単軸圧縮における応力を $\sigma$, 塑性ひ ずみを $\varepsilon_{p}$ とすれば

$$
\left.\begin{array}{l}
\sigma_{11}=\sigma, \quad \text { その他の } \sigma_{i j}=0 \\
\varepsilon_{11}^{p}=\varepsilon^{p}, \varepsilon_{22}^{p}=\varepsilon_{33}^{p}=-\varepsilon^{p} / 2, \text { その他の } \varepsilon_{i j}^{p}=0
\end{array}\right\}
$$

であるから，式 (7)は

$$
\dot{\varepsilon}^{p}= \begin{cases}\frac{1}{H} \dot{\sigma} & \text { 引張り } \\ \frac{1-2 \beta}{H} \dot{\sigma} & \text { 圧縮 }\end{cases}
$$

と書ける。したがって，単軸負荷における引張りと圧縮 の違いを表現するように $\beta$ を決定すればよい.

Fig. 2 は，高密度ポリエチレン (HDPE) ならびにポリ プロピレン (PP) の単軸負荷における応力ーひずみ曲線 を示す．四中の点線は，実験結果 ${ }^{18)}$ を表す。実験方法の 詳細は，文献を参照されたい。また，実線と一点鎖線は， それぞれ式 (10a)ならびに式 (10b)による計算結果を表す。 このとき，以下の材料定数を用いた。
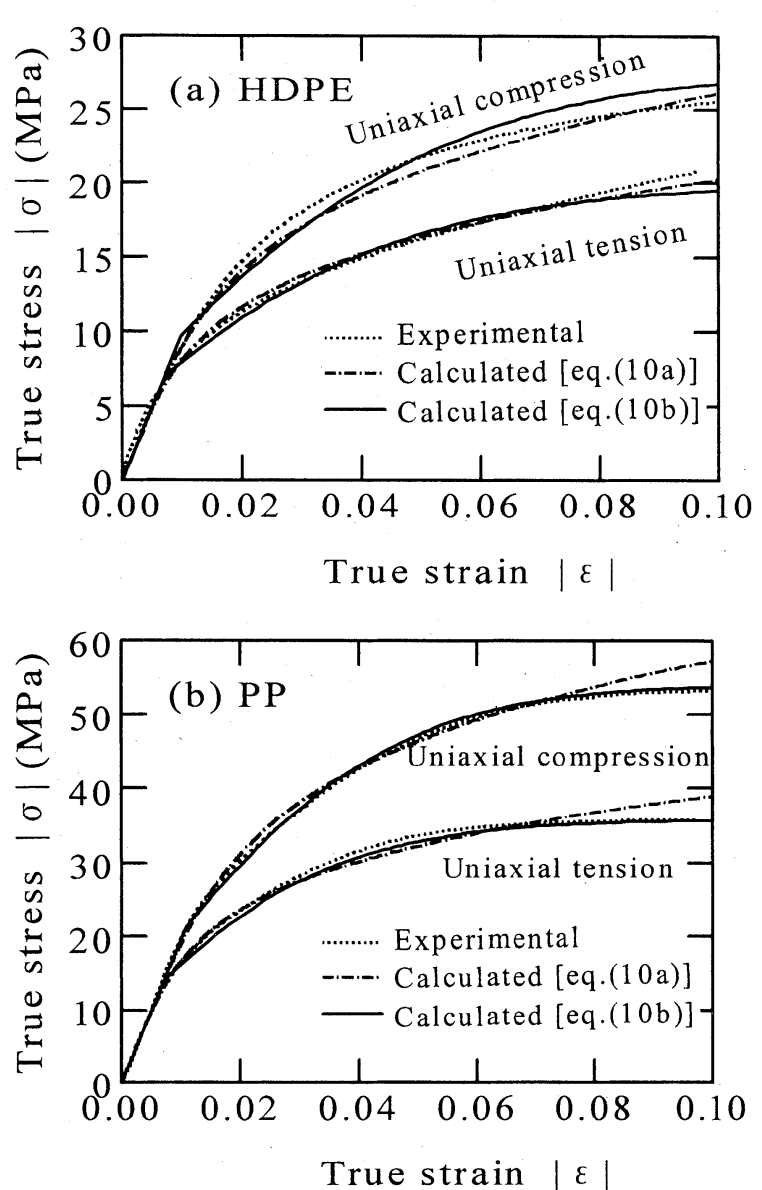

Fig. 2. Stress-strain curves under uniaxial tension and uniaxial compression. 


$$
\begin{aligned}
& E=0.982 G P a, \quad \beta=0.12 \\
& \left.F=37.5 M P a, b=1.0 \times 10^{-4}, n=0.244\right\}(H D P E) \text { (12a) } \\
& \sigma_{Y}=7.0 \mathrm{MPa}, \sigma_{Y}^{*}=20.0 \mathrm{MPa}, \mathrm{c}=40.0 \\
& E=1.97 G P a, \quad \beta=0.17 \\
& \left.F=67.2 M P a, b=1.0 \times 10^{-4}, n=0.217\right\}(P P) \\
& \sigma_{Y}=14.0 M P a, \sigma_{Y}^{*}=35.7 M P a, c=60.0
\end{aligned}
$$

ここで $F, b, n, \sigma_{Y}, \sigma_{Y}^{*}, c$ の值は, 単軸引張りの応 カ一塑性ひずみ曲線を記述するように決定した，次に $\beta$ の値は，圧縮挙動を表現するように定めた。

図から式 (10a) と式 (10b)のいずれの関数形を用いても 実験結果を比較的精度良く記述できることがわかる。詳 細に見れば, 式 (10a) は式 (10b) と比べて初期降伏後の滑 らかな応力ーひずみ関係を精度良く表現できるけれども 大きなひずみで応力值を少し大きめに見積もる傾向に ある。

\section{$3 \cdot 2$ 多軸組合せ負荷における計算結果}

ここでは，多軸組合せ負荷の例として，等二軸引張り， 等二軸圧縮ならびに単純せん断における計算結果を示す。 まず等二軸引張りおよび等二軸圧縮に打ける応力を $\sigma$, 塑性ひずみを $\varepsilon_{p}$ とすれば

$$
\left.\begin{array}{l}
\sigma_{11}=\sigma_{22}=\sigma, \text { その他の } \sigma_{i}=0 \\
\varepsilon_{11}^{p}=\varepsilon_{22}^{p}=\varepsilon^{p}, \varepsilon_{33}^{p}=-2 \varepsilon^{p}, \text { その他の } \varepsilon_{i j}^{p}=0
\end{array}\right\}
$$

となるので, 式 (7)は次のように書ける.

$$
2 \dot{\varepsilon}^{p}= \begin{cases}\frac{1+\beta}{H} \dot{\sigma} & \text { 第二軸引張り } \\ \frac{1-3 \beta}{H} \dot{\sigma} & \text { 第二軸圧縮 }\end{cases}
$$

次に単純せん断に打けるせん断応力を $\tau$ ，せん断ひずみ を $\gamma_{p}$ とすれば

$$
\left.\begin{array}{l}
\sigma_{12}=\sigma_{21}=\tau, \text { その他の } \sigma_{i j}=0 \\
\varepsilon_{12}^{p}=\varepsilon_{21}^{p}=\gamma^{p} / 2, \text { その他の } \varepsilon_{i j}^{p}=0
\end{array}\right\}
$$

なので, 式 (7)は次のようになる.

$$
\frac{\dot{\gamma}^{p}}{\sqrt{3}}=\frac{1-\beta}{H}(\sqrt{3} \dot{\tau})
$$

Fig. 3 の実線と一点鎖線は，それぞれ式 (10b) および 式 (10a) を用いた式 (13)，(14)による計算結果を表す. 四には参考のために式 (11) による単軸引張りと単軸圧 縮の計算結果も示す。なお，この計算には (12b) の材料 定数を用いて行った.

困から組合せ負荷状態によって，著しく異なる予測を することがわかる．等二軸引張りと等二軸圧縮における 計算結果が最も異なるので，このような負荷条件に扔け る実駼結果と比較することによって理論の妥当性を検討 する必要がある．また Fig. 2 と同様に，多軸組合せ負荷 においても式 (10a) と式 (10b)による計算結果に大きな差 異はない.な技， $\beta=0$ (Misesの降伏曲面）とすれば, いずれの計算結果も単軸引張りの計算結果と一致する.

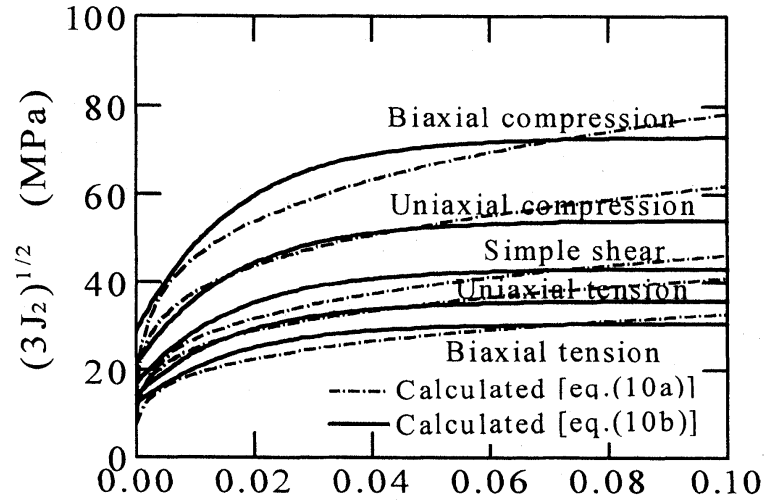

Effective plastic strain

Fig. 3. Stress-plastic strain curves under multiaxial stress.

$3 \cdot 3$ 高圧力下における計算結果と実験結果との比較 ここでは, 従来報告されている高圧力下における種々 の実験結果 ${ }^{8), 10)}$ と本モデルによる計算結果を比較する.

まずFig. 4 は, Spitzig と Richmond ${ }^{10)} に よ る$ 種々の静 水圧力下に打りる単軸引張りと単軸圧縮の実験結果なら びに本構成式モデルによる計算結果を示す．図中の各記 号の内 $\bigcirc \nabla \triangle \diamond \square$ 㧒は， $p=0.101 ， 138,276,552,828$,

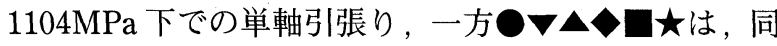
じ圧力下での単軸圧縮を表す。また，実線と破線はそれ ぞれ式 (10b) による単軸引張りならびに単軸圧縮の計算 結果を表す。さらに, 一点鎖線と二点鎖線は式 (10a) に よる単軸引張りならびに単軸圧縮の計算結果を示す。計 算には, 以下の材料定数を用いた。

$$
\left.\begin{array}{l}
E=1140+5 p M P a, \quad \beta=0.035 \\
F=40.0 M P a, b=1.0 \times 10^{-4}, n=0.172 \\
\sigma_{Y}=13.0 M P a, \sigma_{Y}^{*}=28.5 M P a, c=30.0
\end{array}\right\}(H D P E) \quad(15 \mathrm{a})
$$

$$
\left.\begin{array}{l}
E=2350+3 p M P a, \quad \beta=0.050 \\
F=100 M P a, b=1.0 \times 10^{-4}, n=0.114 \\
\sigma_{Y}=40.0 M P a, \sigma_{Y}^{*}=6898 M P a, c=100
\end{array}\right\}(P C)
$$

ここで縦弾性係数の圧力依存性は，文献 10)に報告され ている値を用いた。次に $F, b, n, \sigma_{Y}, \sigma_{Y}^{*}, c$ の値は, 大気圧力下での単軸引張りの応力一塑性ひずみ曲線を記 述するように決定した．最後に $\beta$ の値は，大気圧力下で の圧縮挙動を表現するように定めた。

図から本モデルは，高圧力下での実験結果を比較的よ く記述することがわかる．詳細に見れば，高圧力下での 初期降伏応力を過大に見積もる，そのことは，特にPC に打いて著しい。これは，主に初期降伏応力と後続降伏 応力で静水圧依存性が異なってくることに起因し，この ような静水圧の影響を適切に表現することによって記述 できる. ${ }^{19)}$ また, 式 (10a) と式 (10b)による計算結果に大き な差異はないことがわかる.

次に, Fig. 5 は Silano らによる種々の静水圧力下にお 


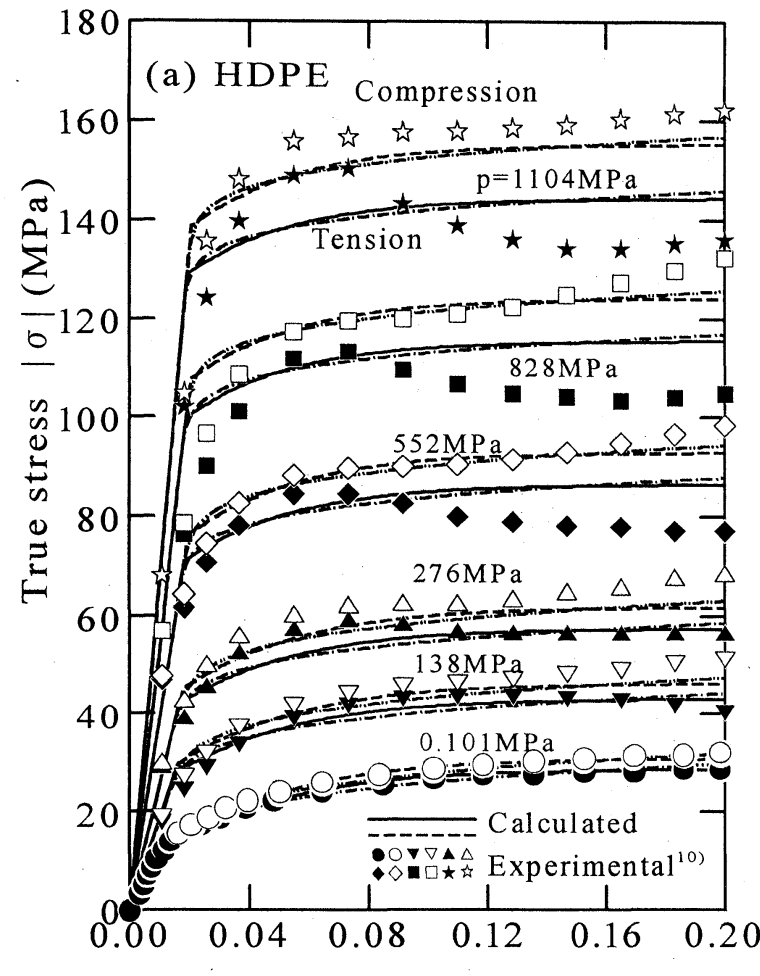

True strain $|\varepsilon|$

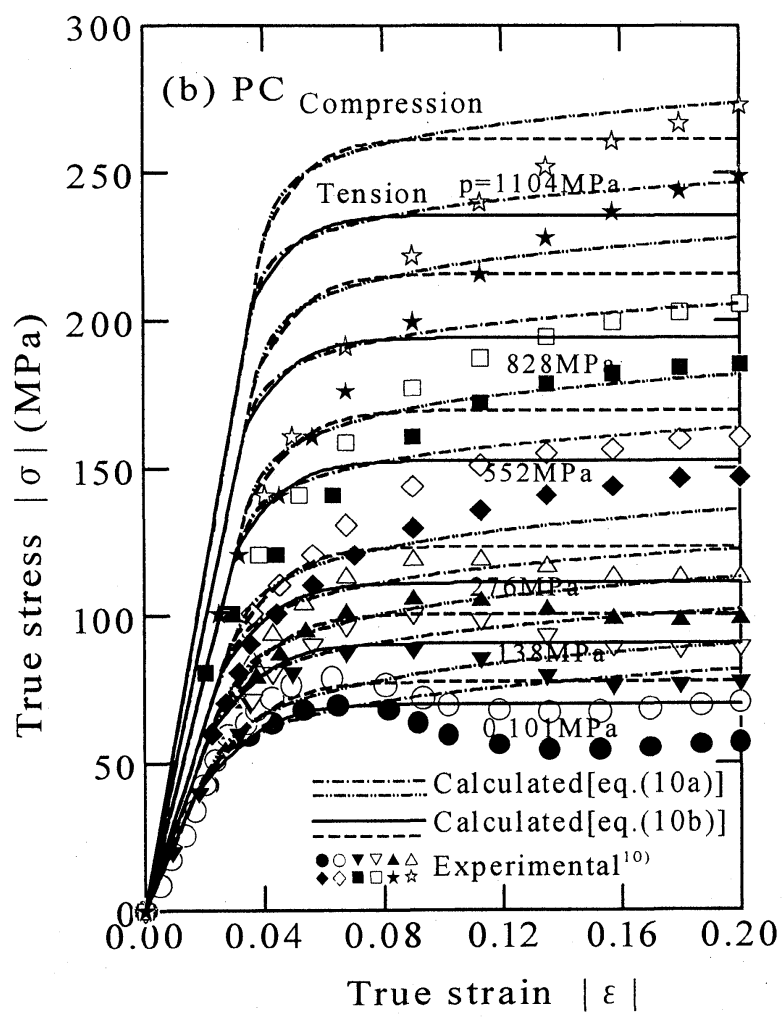

Fig. 4. Tensile and compressive stress-strain curves at various hydrostatic pressures.

ける POM のねじり試験結果 ${ }^{8)}$ ならびに本構成式モデル による計算結果を示す．図中の各記号の内 $\bigcirc \diamond \square \nabla は ，$ それぞれ $p=0.101,200,400,600 \mathrm{MPa}$ 下での実験結果を 表す．また，実線と一点鎖線は，旮れぞれ式 (10a)なら びに式 (10b)による計算結果を表す。計算には, 以下の

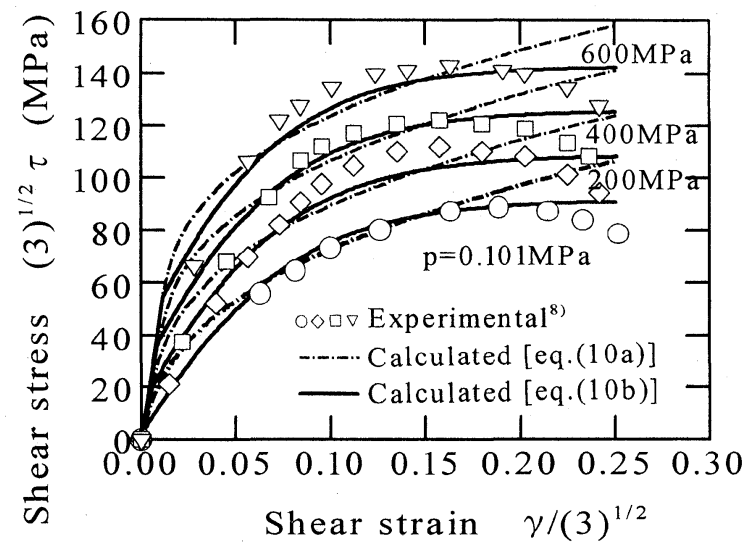

Fig. 5. Shear stress-strain curves at various hydorostatic pressures.

材料定数を用いた.

$$
\left.\begin{array}{l}
G=955+p M P a, \quad \beta=0.0277 \\
F=182 M P a, b=1.0 \times 10^{-4}, n=0.366 \\
\sigma_{Y}=3.36 M P a, \sigma_{Y}^{*}=98.0 M P a, c=23.0
\end{array}\right\}
$$

図から本モデルは, 高圧力下でのねじり試験結果も比較 的よく記述することがわかる。 また, 式 (10a) は式 (10b) と比べて大きなひずみで応力值を少し大きめに見積もる 傾向にある。

\section{4 結 論}

静水圧依存性のある降伏曲面と非連合流れ則を用い て, 高分子材料の塑性構成式モデルを定式化した. 本モ デルによる計算結果ならびに従来の実験結果との比較か ら以下の結論を得た。

（1）本モデルは，単軸引張りと単軸圧縮の実験結果を 適切に表現できた。単軸引張りの応力一塑性ひずみ曲線 を適切に記述できる関数形であれば，他の負荷における 計算結果に大きな差異はない.

（2）本モデルは，多軸組合せ負荷によって，Mises 型 の相当応力一相当ひずみ曲線において著しくことなる予 測をする. 平面応力状態では, 等二軸引張りと等二軸圧 縮の計算結果が最も異なる。

（3）本モデルは，高圧力下の実験結果をほぼ記述す る. ただし, 高圧力下では初期降伏応力と後続降伏応力 の静水圧依存性が異なるので, 精密化にはこれを適切に 表現する必要がある.

\section{参 考 文 献}

1) E. Krempl, Transactions of the ASME, Journal of Engineering Materials and Technology, 101, 380 (1979).

2）北川正義，松谷智彦，材料， 37, 1391 (1988).

3）有山 堯，佐久間通之，金子堅司，日本機械学会論文集， A-58, 2345 (1992).

4) M. C. Boyce, D. M. Parks and A. S. Argon, Mechanics of Materials, 7, 15 (1988).

5) 冨田佳宏, 日本機械学会論文集, A-66, 420 (2000).

6) D. R. Mears, K. D. Pae and J. A. Sauer, Journal of Applied 
Physics, 40, 4229 (1969).

7 ) S. Rabinowitz and I. M. Ward, Journal of Material Science, 5, 29 (1970).

8 ) A. A. Silano, K. D. Pae and J. A. Sauer, Journal of Applied Physics, 48, 4076 (1977).

9 ) C. Bauwens-Crowet, J.-C. Bauwens and G.Homés, Journal of Material Science, 7, 176 (1972).

10) W. A. Spitzig and O. Richmond, Polymer Engineering and Science, 19, 1129 (1979).

11) A. W. Christiansen, E. Bear and S. V. Radcliffe, Phil. Mag., 24, 451 (1971).

12) P. B. Bowden and J. A. Jukes, Journal of Material Science, 7, 52 (1972).

13) R. Raghava, R. M. Caddell and G. S. Y. Yeh, Journal of
Material Science, 8, 225 (1973).

14) A. L. Gurson, Transactions of the ASME, Journal of Engineering Materials and Technology, 99, 2 (1977).

15) A. Needleman and V. Tvergaard, J. Mech.Phy. Solids, 32, 461 (1984).

16) S. Nemat-Nasser, M. M. Mehrabadi and T. Iwakuma (S. Nemat-Nasser 編), “Three-Dimensional Constitutive Relations and Ductile Fracture”, p.157 (1981) Noth-Holland Publishing.

17) 増㴊雄一, 滝本淳一, 小山清人, 成形加工, 11,102 (1999)

18）、佐野村幸夫，日本材料学会第 9 回高分子材料シンポジウ 么, 30 (1999)

19）佐野村幸夫, 日本機械学会 2000 年度年次大会講演論文集, Vol. I, 167 (2000).

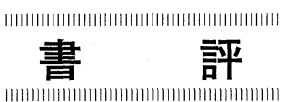

\section{“二元合金状態図集”}

長崎 誠三, 平林 眞 編著

(2001 年，アグネ技術センター発行，A5 版，365 ページ，本体価格 5600 円)

合金の状態図は，ハードな出版物ばかりでなく，成分を与えて計算によって求められるソフトが開発されたり，電子的 データベースの著しい進歩に伴って ASM international をはじめ学会や研究機関で集積されたり，CD-ROM 化され，容 易に入手したり，インターネットによるアクセスが可能になっている.

しかし, 合金設計, 相変態の解析をはじめとする材料特性の基礎研究に打いては, 研究者や技術者が, いちいち図書 館に行ったり, コンピュータ画面をクリックして改めて構えなくても, 典型的な合金の状態図を, 手元においた簡便な図 書から直ぐに見ることができることは極めて重要である.

本書は，このような立場から，金属物理学の良書を多く刊行し，学術の発展に寄与している当出版社を主宰して, 先 年逝去された故長崎氏と, 金属学のわが国におけるメッカともいうべき東北大学金属材料研究所の所長をされた平林氏 が, 600 種類を越える状態図を手際よく小冊子にまとめたものである. とくに, わが国のデータを重視した点, 金属と水 素や酸素などの侵入型合金を置換型と大別して整理していることが特徴として挙げられる．また，状態図の見方，歴史 などが要領よくまとめられているのはすばらしい. 